\title{
Antilaicismo, anticomunismo y críticas a la masonería en la prensa católica salvadoreña durante el retorno del debate de la laicidad del Estado (1938-1940)
}

\author{
Anti-Laicism, Anti-Communism and Criticism to Freemasonry in \\ the Salvadorian Catholic Press during the return to the debate on the \\ Laicism of the State (1938-1940)
}

\author{
René Antonio Chanta Martínez \\ Universidad Don Bosco, El Salvador \\ rene.chanta@aol.com
}

Recepción: 13 de febrero de 2018/Aceptación: 15 de mayo de 2018. doi: https://doi.org/10.15517/rehmlac.v10i1.32419

Palabras clave

Iglesia católica; comunismo; laicismo; prensa católica; masonería.

Keywords

Catholic Church; El Salvador's State; Communism; Laicism; Catholic Press; Freemasonry.

\section{Resumen}

A pesar de que el debate sobre la laicidad del Estado salvadoreño en el siglo XIX sea de notable actualidad, ya en pleno siglo XX, lejos de disminuir, se profundizó y se vivió con más intensidad cuando se estaba fraguando la Constitución de 1939. En base a lo anterior, analizamos una serie de textos anti laicistas y anticomunistas aparecidos en los periódicos católicos Criterio y Chaparrastique. En estos textos es llamativo observar tres situaciones: A) La dura crítica hacia la masonería en el discurso católico anti-laicista; B) El fuerte énfasis en el contexto internacional haciendo referencia a los países o regiones en donde los gobiernos realizaban cambios y leyes en favor del catolicismo; C) La esperanza de los grupos católicos en revertir la laicidad promovida en la Constitución de 1886 con una nueva carta magna que le diera más derechos y beneficios a la Iglesia católica.

\begin{abstract}
Although the $19^{\text {th }}$ century debate on the laicism has been a recurrent in El Salvador, far from being over in the $20^{\text {th }}$ century, it was intensely fought when its 1939 Constitution was being forged. Based on this, this article's objective is to present an analysis of a series of anti-secular and anti-communist texts, found in catholic newspapers like Criterio and Chaparrastique. Three situations are interesting to note in these texts: A) The hard criticism exerted towards masonry in the anti-secular discourse; B) The strong emphasis given by catholic groups to the international context to make reference to governments that were making changes in favor of Catholicism; C) The hope of the catholic groups to revert the laicism of the State through a new Constitution of the Republic that would give the Catholic Church more rights and benefits.
\end{abstract}

\section{Introducción}

El presente trabajo pretende realizar una aproximación al discurso católico antiliberal y anticomunista que fue emitido en diversos documentos escritos a mediados del 
siglo XX en el territorio salvadoreño. Como fuentes primarias centrales, se han consultado los periódicos católicos Chaparrastique ${ }^{1}$ y Criterio $^{2}$ junto con algunas cartas pastorales de monseñor Chávez y González ${ }^{3}$ que en este tiempo era el Arzobispo de la capital. También se ha tenido acceso a las pastorales colectivas que emitió la Conferencia Episcopal de El Salvador. Conviene advertir que de ninguna manera se pretende hacer un estudio exhaustivo sobre este tema. Más bien, esta investigación se limitará al periodo de tiempo comprendido entre 1938 y 1940 cuando el país vivía una fuerte reestructuración del aparato estatal producto de varios acontecimientos que marcaron la política salvadoreña durante los últimos años de la década de los años treinta del siglo XX. En efecto, en 1938 se celebraron elecciones para elegir a los diputados de la Asamblea Constituyente que redactarían un nuevo texto constitucional luego de 53 años de haber estado vigente la Constitución de 1886. De esta manera, cuando se estaba fraguando esta Constitución, se emitieron en los medios impresos católicos fuertes críticas hacia el comunismo y el liberalismo. En algunos de estos textos, los sectores católicos identificaron a los miembros de la masonería salvadoreña como los principales representantes de la introducción, difusión y propagación de las posturas laicistas. A la vez, los grupos católicos guardaban la esperanza de poder revertir los artículos constitucionales que afectaban los intereses de la Iglesia católica y que habían sido promovidos por la Constitución de $1886^{4}$.

Teniendo en cuenta lo anterior, este trabajo tendrá tres partes. Primero se hará una rápida visión respecto a los antecedentes de la Constitución de 1939. Ahí un tema fundamental a resaltar es que El Salvador pasó de ser un Estado con constituciones

\footnotetext{
${ }^{1}$ Chaparrastique fue un periódico católico que inició su vida en 1915 bajo la dirección del presbítero Dr. Vicente de Jesús Gómez. Escribieron en este rotativo Oscar Arnulfo Romero y monseñor Rafael Valladares y Argumedo. Durante muchos años tuvo un acentuado tono antimasónico. Para más información puede verse, mi artículo: "Antimasonería y antiliberalismo en el pensamiento de Oscar Arnulfo Romero (1962-1965)", REMHLAC 3, no $1 . \quad$ (mayo-noviembre 2011): 121-141, https://revistas.ucr.ac.cr/index.php/rehmlac/article/view/6589/6280. A la vez, para tener una visión completa de los periódicos de El Salvador se puede consultar el texto de Ítalo López Vallecillos El periodismo en El Salvador (San Salvador: UCA Editores, 1987).

${ }^{2}$ De acuerdo a Ítalo López Vallecillos, Criterio fue fundado por el Sr. Carlos Alberti Siri y comenzó a circular en 1932. Su lema era "Periódico de defensa". Se dedicó a promover la religión católica y a realizar una fuerte campaña moralizadora. Este periódico se encuentra disponible en la Hemeroteca del Museo Nacional de Antropología David J. Guzmán en donde se encuentran presentes las ediciones de 1950. También existe un considerable número de ediciones de este periódico en el Archivo Histórico del Arzobispado de San Salvador. Conviene advertir que, en la década de los cincuentas, este periódico comenzó a llamarse Orientación y ha continuado sus operaciones hasta el día de hoy.

${ }^{3}$ Monseñor Luis Chávez y González fue Arzobispo de San Salvador desde 1938 hasta finales de 1977. Ha sido uno de los arzobispados más largos en la historia de El Salvador. En total durante 39 años dirigió la Arquidiócesis de San Salvador. Para más datos consultar, Juan Ramón Vega, Las 54 Cartas pastorales de Monseñor Luis Chávez y González (San Salvador: Ediciones del Arzobispado de San Salvador, 1997).

${ }^{4}$ La Constitución de 1886 fue realizada con grandes debates entre sectores que defendían a la Religión católica y los grupos que eran partidarios de un Estado salvadoreño laico. Como punto fundamental de ese texto Constitucional resalta la proclamación de la educación pública salvadoreña como "laica". Al respecto véase, Roberto Valdés, "Masones, liberales y ultramontanos salvadoreños: Debate político y constitucional en algunas publicaciones impresas, durante la etapa final del proceso de secularización del Estado salvadoreño (1885-1886)" (Tesis de doctorado en filosofía iberoamericana, Universidad Centroamericana "José Simeón Cañas", 2010).
} 
protectoras de la Iglesia católica a ser un Estado de tendencia laica. Un texto al cual hay que hacer referencia de manera ineludible en ese proceso es la Constitución de 1886 ya que es una de las más liberales en la historia de El Salvador y en ella participaron varios diputados masones. Posteriormente, se mostrarán los debates que surgieron en el seno de la Asamblea Constituyente de 1939 sobre los asuntos religiosos y la laicidad del Estado. Finalmente, se hará referencia a algunos textos de los impresos católicos en donde se podrá evidenciar el fuerte discurso anticomunista y antiliberal junto con las críticas a la masonería que se emitieron en el contexto de la nueva Constitución.

\section{Antecedentes constitucionales de la Carta Magna de 1939. De unas Constituciones protectoras de la Iglesia católica a una Constitución con enfoque laico}

Desde la época de la independencia centroamericana hasta 1864, El Salvador tuvo varios textos constitucionales. En cada uno de ellos se llega a afirmar que la religión oficial del Estado es la católica, apostólica y romana. Si quisiéramos hurgar los antecedentes próximos de la confesionalidad católica del Estado salvadoreño habría que voltear la mirada a tres documentos fundamentales: la Constitución de Bayona, la Constitución Política de la Monarquía Española de 1812 y el Acta de independencia de Centroamérica. En el primero de estos documentos, es decir, la Constitución de Bayona, puede verse la alta influencia que tuvo la ilustración en España y en sus colonias americanas. En efecto, Napoleón presentará el proyecto de esta Constitución en 1807 y un año después será promulgada en el marco de la invasión francesa a la península española ${ }^{5}$. En dicha Constitución se establece la inviolabilidad del domicilio, la libertad de imprenta y la igualdad de la colonia con la metrópolis entre otros derechos de tipo liberal. A la vez, se reconoce al Rey como el fundamento del sistema constitucional. No obstante lo anterior, el artículo primero de la Constitución de Bayona ${ }^{6}$ nos dice que la religión Católica, Apostólica y Romana es la del rey y la de la nación. Cabe precisar que el nivel de influencia de esta Constitución fue limitado ya que no fue aceptada ni por el pueblo español ni por lo que se conoció como la Capitanía General de Guatemala ya que esta última acabó

\footnotetext{
${ }^{5}$ Recordar que, en este tiempo, Napoleón dominaba el territorio español y decidió elevar al trono español a su hermano José Bonaparte. En ese contexto, Napoleón también decidió convocar a una junta para redactar un texto constitucional que regiría a España durante ese tiempo. Dicha junta operó entre los meses de junio y julio y el texto definitivo y aprobado se publicó en La Gaceta de Madrid. Al respecto, consúltese, Gaceta de Madrid, 27, 28, 29 y 30 de julio de 1808. Para toda esa época podría ser útil el texto de Juan Mercader Riba, José Bonaparte, Rey de España (1808-1813) (Madrid: Consejo Superior de Investigaciones Científicas, 1983).

6 A este documento también se le conoce con el nombre de "Estatuto de Bayona". Para muchos estudiosos, este texto fue la primera Constitución española. Esto es un tema de discusión ya que, para otros especialistas, el primer texto constitucional en España fue la Constitución de Cádiz de 1812. Para más información al respecto, véase: Ignacio Fernández Sarasola, "La primera Constitución española. El estatuto de Bayona", Revista de Derecho 26 (2006): 89-109.
} 
reconociendo el juramento de fidelidad a Fernando VII de España ${ }^{7}$. Sin embargo, de acuerdo a algunos especialistas tales como Ignacio Fernández Sarasola y Hernán Olano García, el texto de la Constitución de Bayona sirvió en alguna medida como fundamento a la Constitución de Cádiz ${ }^{8}$.

Como es sabido, la Constitución de Cádiz ${ }^{9}$ fue aprobada el 19 de marzo de 1812 y ella será una de las influencias e inspiraciones más grandes no solamente para emancipar a las nuevas naciones americanas ${ }^{10}$, sino que también, Cádiz llegaría a sembrar uno de los pilares esenciales para que la Iglesia católica sea reconocida y protegida constitucionalmente en las recién formadas naciones centroamericanas ${ }^{11}$. En efecto, dicha Constitución establece en su artículo 12 que la religión oficial de la nación española es la católica prohibiendo el ejercicio de otras religiones. Finalmente, para ver esta continuidad heredada de la época colonial hay que hacer referencia al Acta de independencia que se firmó en el Palacio Nacional de Guatemala ${ }^{12}$ el 15 de septiembre de 1821. En el numeral 10 de dicho documento se afirma que el Estado debe velar porque la religión católica se conserve pura e inalterable ${ }^{13}$. Dos años más tarde, en la misma línea del acta de independencia, el decreto de la Asamblea Nacional Constituyente del 2 de julio de $1823^{14}$ en el segundo numeral nos dice lo siguiente: "La religión de las provincias Unidas, es la Católica [...] que nuestra separación de la antigua España en nada perjudica ni debilita nuestra unión a la Santa Sede, en todo lo concerniente a la Relijión Santa de Jesucristo"15. Ese reconocimiento a la Iglesia católica le daba a ella ciertos privilegios y protecciones. Quizás uno de los sectores más beneficiados con ello serían los miembros del clero ya que

7 Edwin Castro Rivera y Margine Calderón Marenco, Derecho Constitucional Nicaragüense (Managua: Colección Facultad de Ciencias Jurídicas UCA, 2007), 9.

${ }^{8}$ Hernán Olano García, La Constitución de Bayona. Precursora del constitucionalismo hispanoamericano, (Bogotá: Academia Colombiana de Jurisprudencia, 2014). Ignacio Fernández Sarasola, La Constitución de Bayona (1808) (Madrid: IUSTEL, 2007).

${ }^{9}$ Constitución Politica de la Monarquía Española de 1812 (Madrid: Edición conjunta de la Agencia Estatal Boletín Oficial del Estado, la Biblioteca Nacional de España, el Centro de Estudios políticos y Constitucionales y el consorcio para la Conmemoración del II Centenario de la Constitución de 1812, 2011).

${ }^{10}$ Alberto Ramos Santana coord., La Constitución de Cádiz y su huella en América (Cádiz: Universidad de Cádiz-Banco Santander, 2011), 298.

${ }^{11}$ José Antonio Ferrer Benimelli, "Utopía y realidad del liberalismo masónico. De las Cortes de Cádiz a la independencia de México", en 300 años: masonerías y masones 1717-2017, eds. Ricardo Martínez Equivel, Yván Pozuelo Andrés y Rogelio Aragón (Ciudad de México: Palabra de Clío, 2017). Este texto de Ferrer Benimelli aunque no trata directamente las reflexiones hechas en Centroamérica, si presenta detalladamente el discurso masónico y antimasónico en México desde las cortes de Cádiz hasta la independencia.

${ }^{12}$ No hay que olvidar en esta sección el factor económico que estuvo presente en este tiempo. Las reformas borbónicas impulsaron ciertas modificaciones en la economía y la organización del territorio. Así, en 1785 se crea la Intendencia de San Salvador lo cual a la larga iba a producir cambios no solo sociopolíticos, sino que también económicos. Y, hay que remarcar que antes de la independencia, el producto que dominaba la producción nacional era el añil. Para más datos consultar Héctor Lindo, La economía de El Salvador en el siglo XIX (San Salvador: CONCULTURA, 2002), 9-59.

${ }^{13}$ Cfr. Texto de "Actas de independencia y los primeros decretos constitucionales" en Ricardo Gallardo, Las Constituciones de la República Federal de Centro-América (Madrid: Instituto de estudios políticos, 1958), 663.

${ }^{14}$ Como fruto de esta Asamblea Nacional Constituyente surgió la Constitución Federal de Centroamérica.

${ }^{15}$ Ricardo Gallardo, Las Constituciones de la República Federal de Centro-América, 677-678. 
en el artículo 92 de la Constitución Federal de Centroamérica se afirmó que los senadores que designe cada Estado podían ser miembros del clero ${ }^{16}$. De esta manera no se excluía a los sacerdotes de las labores y cargos políticos. Esto aplicaba necesariamente a El Salvador ya que este Estado pertenecía a la República Federal ${ }^{17}$. Teniendo en cuenta la Constitución de Cádiz y la tradición colonial, la protección a la Iglesia católica se reflejará también en el primer texto constitucional salvadoreño emitido en 1824. En efecto, en el artículo quinto de dicha Carta Magna se afirma que la religión católica es la del Estado y se excluye el culto de las otras confesiones religiosas ${ }^{18}$.

Diecisiete años más tarde se va a promulgar una nueva Constitución. Era el año de 1841, época en la cual ya se había disuelto la República Federal y cada uno de los Estados comenzaba su vida separadamente. El nuevo texto constitucional, inicia invocando el nombre de Dios, llamándolo supremo Hacedor y Legislador del Universo. A la vez, se rescata la protección a la Iglesia católica en el capítulo tercero de dicho documento. No obstante, se puede vislumbrar un rompimiento con la tradición pasada ya que, se empieza a considerar seriamente la libertad de todo ser humano de adorar a Dios según su conciencia $^{19}$.

En 1864 se redactó lo que podríamos considerar la última constitución del siglo XIX que protege a la Iglesia católica. Esta constitución fue realizada durante la administración del presidente Francisco Dueñas ${ }^{20}$ en marzo de ese año. Con esto, quedaba abolida la Carta Magna de 1841 que había regido al país durante casi 23 años. En esta Constitución se nombra a Dios en el prólogo. El titulo segundo de la Constitución de 1864 se titula "Del territorio, forma de gobierno y religión". Al realizar una lectura rápida del texto, es llamativo el artículo cuarto en donde se expresa que: "La religión Católica, Apostólica y Romana, única verdadera, profesa El Salvador, y el gobierno le dará su protección" 21 . Este artículo no es novedoso ya que las constituciones anteriores también reconocen a la Iglesia católica como verdadera y le garantizan protección. Sin embargo, si lo comparamos con el artículo tercero del anterior texto Constitucional, puede verse que es un artículo más corto y

${ }^{16}$ El artículo 92 de la Constitución de la República Federal de Centroamérica dice que: "Uno solo de los senadores que nombre cada Estado podrá ser Eclesiástico".

${ }^{17}$ Para esta sección puede ser muy sugerente consultar el texto compilado por Miguel Ángel Gallardo, Cuatro constituciones federales de Centro América y las constituciones políticas de El Salvador (San Salvador: Tipografía La Unión, 1945).

${ }^{18}$ El artículo 5 de la Constitución del Estado del Salvador de 1824 dice lo siguiente: "La religión del Estado es la misma que la de la República, á saber; la C.A.R; con exclusión del exercicio público de cualquier otra". Texto tomado de la obra de Ricardo Gallardo, Las Constituciones de El Salvador (Madrid: Ediciones de Cultura Hispánica, 1961), Tomo II, 299. Como bien podrá deducirse, las iniciales C.A.R. significa católica, apostólica y romana.

${ }^{19}$ Esto aparecería en el artículo tercero de la Constitución de 1841.

${ }^{20}$ Francisco Dueñas fue presidente de la República de El Salvador entre 1863 y 1871. En este último año fue derrocado por la Revolución de 1871 que a la postre dejó como presidente a Santiago González. Fue también Rector de la Universidad de El Salvador de 1848 a 1854.Para más datos de esta época puede consultarse, Rodolfo Cardenal, El poder eclesiástico en El Salvador (San Salvador: CONCULTURA, 2001), 59-65.

21 "Constitución de la República de El Salvador, 1864", http://www.cervantesvirtual.com/obravisor/constitucion-politica-de-la-republica-de-el-salvador-de-1864/html/74441e80-6747-410e-ae29$\underline{\text { 0d02a00bfde1_2.html }}$ 
desaparece el apartado en donde se afirmaba la libertad de conciencia de las personas creyentes. A la vez, una diferencia crucial entre la Constitución de 1864 y la de 1841 es que va a desaparecer el artículo que afirmaba que ningún eclesiástico podrá ser electo presidente, senador o diputado ${ }^{22}$. Por tanto, la Constitución de 1864 dejaba abierta nuevamente la posibilidad de que un eclesiástico pudiera ser diputado y parecería un continuismo con los textos constitucionales desde la época de la República Federal.

\section{El tiempo de rupturas:}

\section{Desde la Constitución de 1871 a la Constitución de 1886}

Con estas evidencias podríamos decir que en la época de los primeros años de vida independiente de El Salvador, las constituciones se comprometieron a proteger a la Iglesia católica $^{23}$. Sin embargo, a partir de 1871 se puede notar un cambio de marcha en las Constituciones salvadoreñas en los aspectos referentes a las relaciones entre la Iglesia y el Estado. En efecto, desde ese momento ya se iba a iniciar una progresiva secularización del Estado salvadoreño que culminaría en $1886^{24}$. Varios de los artículos laicizantes ocasionaron inconformidad, molestias y protestas de parte de los sectores católicos. Por ejemplo, un artículo problemático de la Carta Magna de 1871 fue el sexto, ya que, aunque nuevamente se protegería a la religión católica, también se enfatizaba que se toleraría el culto de las otras religiones siempre y cuando no ofendieran la moral ${ }^{25}$. Otro artículo polémico de esta constitución fue sin duda el número 23. Ahí se afirma que: "Ningún eclesiástico podrá obtener cargo de elección popular" ${ }^{26}$. Con esto, las intenciones de los redactores de la Constitución de 1871 era realizar una especie de blindaje para impedir que los sacerdotes pudieran ser dirigentes de la nación ya sea como presidentes o como diputados. Reservarían estos puestos únicamente a los seglares que cumplieran con las disposiciones de la Constitución. Curiosamente, hay que decir que durante este tiempo (1871) es cuando se fundan las primeras logias masónicas en El Salvador. La primera en

\footnotetext{
${ }^{22}$ En la Constitución de 1841 el artículo 12 afirmaba que ningún eclesiástico podía ser electo presidente, senador o diputado.

${ }^{23}$ No obstante, también hubo conflicto ya que desde la época de la presidencia de Gerardo Barrios hubo tensiones entre la Iglesia y el Estado lo cual incluso significó la expulsión de sacerdotes y obispos del territorio nacional. Para más información consúltese: Cardenal, El Poder Eclesiástico en El Salvador, 109. Jesús Delgado, Historia de la Iglesia en El Salvador (San Salvador: Dirección de Publicaciones e Impresos, 2013), 355 .

${ }^{24}$ Un estudio reciente en donde se muestra el paso de una educación católica a una educación de inspiración laica en El Salvador seria: Julián González, "Del ciudadano Católico al Ciudadano laico" (Tesis de doctorado en filosofía iberoamericana, Universidad Centroamericana, "José Simeón Cañas", 2012). A la vez para mayor amplitud sobre el tema, consultar, Olga Vásquez Monzón, "El debate sobre la educación femenina en el contexto de la laicización del Estado salvadoreño (1871-1889)" (Tesis del doctorado en filosofía iberoamericana, Universidad Centroamericana "José Simeón Cañas", 2012).

${ }^{25}$ Textualmente el artículo 6 dice así: "La Religión Católica, Apostólica y Romana es la del Estado, y el gobierno la protejerá. Se tolerará el culto público de las sectas cristianas en cuanto no ofendan a la moral ni al orden público", en Gallardo, Las Constituciones de El Salvador, Tomo II, 388.

${ }^{26}$ Gallardo, Las Constituciones de El Salvador, 392.
} 
establecerse es la logia "Progreso No 5" en la ciudad de San Salvador. Así, hay evidencias de que algunos masones fueron figuras notables y relevantes en el proceso de laicización del Estado salvadoreño ya sea dirigiendo entidades educativas, siendo parte del aparato estatal como funcionarios, o bien, escribiendo y difundiendo ideas acordes al Estado laico $^{27}$.

El culmen de todo este periodo será la Constitución de $1886^{28}$ ya que allí se respaldó el proceso de laicización que se había venido dando desde 1871 confirmándose la educación del Estado salvadoreño como "laica". Como es ya sabido, esta Constitución fue aprobada con grandes debates en donde los miembros de la masonería jugaron un papel importante a la hora de defender los artículos laicizantes ${ }^{29}$. En efecto, esta Constitución ha sido considerada como la más liberal de la historia salvadoreña y probablemente una de las más laicas. Fueron diputados constituyentes varios masones como: Francisco Esteban Galindo (Logia “Caridad y constancia No 18”), Máximo Mancía (logia “Excelsior no. 17”), Domingo Jimenez ("Excelsior no. 17") 30 . Estas personas, junto con otras defendieron a lo largo de las sesiones de la Asamblea Constituyente temas como la libertad de cultos, la invalidez del voto religioso, la educación laica, frente a los diputados más conservadores afines a la Iglesia católica ${ }^{31}$. De esta forma, 1886 fue la última Constitución de El Salvador que se emitía en el siglo XIX y tal como hemos podido vislumbrar, fue una época de cambios para el Estado salvadoreño. Por supuesto, esto no significó que se pondría fin al conflicto entre las posturas acordes al estado laico y los grupos de tendencia conservadora. Más bien, a través de la prensa puede evidenciarse que dicho debate continuaría en lo que restaba del siglo XIX y en los primeros años del siglo $\mathrm{XX}^{32}$. Aquí conviene diferenciar lo que se entiende por secularización y por laicidad ya que no son conceptos similares ${ }^{33}$.

\footnotetext{
${ }^{27}$ Aquí bien podrían mencionarse figuras como Rafael Reyes quien fuera Alcalde de San Salvador, docente universitario y director de la Escuela Normal de maestros. También es digno de mención Antonio J. Castro, quien fuera funcionario público durante el gobierno de Rafael Zaldívar (también masón, miembro de la Logia "Excelsior"). Puede verse, Valdés Valle, "Origen, miembros y primeras acciones de la masonería en El Salvador", REHMLAC 1, no. 1 (mayo-noviembre 2009): 155-171, https://revistas.ucr.ac.cr/index.php/rehmlac/article/view/6861/6548. También puede consultarse, Francisco J. Ponte, Historia de la masonería salvadoreña (Sonsonate: Imprenta "Excelsior", 1962), 20-24.

${ }^{28}$ Existen también textos constitucionales en 1881 y 1883 promovidas en el tiempo del presidente Rafael Zaldívar.

${ }^{29}$ Para ampliaciones de este debate consúltese, Valdés Valle, "Masones, liberales". Este estudio es interesante porque muestra con detalles los debates de la Constituyente de 1885 cuya Constitución final nunca llegó a promulgarse, pero en general sintoniza bastante con lo propuesto por la Constitución de 1886.

${ }^{30}$ Valdés Valle, "Masones, liberales", 96-97.

${ }^{31}$ No es este el espacio para hacer referencia al complejo panorama que vivía la Iglesia católica de ese momento. Lo cierto es que se había dado una romanización del clero desde los episcopados, situación que se agudizó con Pío IX. A la vez, más tarde se daría el proceso de unificación de Italia lo cual trajo consecuencias fuertes para la Iglesia católica y los Estados pontificios. Para más datos consultar, Juan María Loboa, Historia de la Iglesia. IV Ėpoca contemporánea (Madrid: BAC, 2002); Giacomo Martina, La Iglesia de Lutero a nuestros dias, Vols III y IV (Madrid: Ediciones Cristiandad, 1974).

32 Valdés Valle, "El Porvenir vs El Católico. Masonismo y ultramontanismo periodístico en confrontación", Revista Realidad de ciencias sociales y humanidades 126 (2001): 547-581.

33 Jean Baubérot, "Sécularisation, laïcite, laïcisation", Epam 90 (2013): 31-38. En efecto, para este autor la secularización sería una pérdida o marginación de la religión de la vida cultural y social moderna, mientras
} 
Según Fortunato Mallimaci la secularización sería "el proceso de recomposición cultural de las creencias religiosas de nuestras sociedades capitalistas acompañado de una declinación del poder de las instituciones cristianas y el surgimiento de dominios autónomos de la vida social" 34 . En efecto, el abandono de las prácticas religiosas cristianas en algunas latitudes sería una consecuencia de este fenómeno cultural de la secularización. Por supuesto, la pérdida de poder de la religión no significa necesariamente la pérdida total de la influencia. Por su parte, este mismo autor menciona que la laicidad "es la relación histórica y legal de cada Estado en su relación con la sociedad política, civil y religiosa" ${ }^{35}$. En efecto, en varios lugares de América latina se estaban dando procesos de laicidad de los Estados. Países como El Salvador y otros estaban reformando sus constituciones para dar libertad de cultos y educación laica en sus naciones. Eso realmente es laicidad ya que hace alusión a un proceso legal y político de un país ${ }^{36}$. Dicho esto, veamos a continuación cual fue el debate sobre la laicidad del Estado salvadoreño que se abrió en la tercera década del siglo XX.

\section{La década de 1930:}

\section{El nacimiento de una nueva Constitución de la República.}

La década de los años treinta del siglo XX fue decisiva para que en El Salvador se dieran procesos de cambio. En efecto, desde el golpe de Estado de 1931, el país iba a iniciar un largo periodo de gobiernos militares que cambiarían el rumbo de la nación ${ }^{37}$. De acuerdo a Juan Mario Castellanos, estos gobiernos militares pusieron fin a lo que se había concebido como el "Estado liberal". En efecto, con el gobierno de Maximiliano Hernández Martínez $^{38}$, El Salvador pasó de ser un Estado oligárquico-liberal a un Estado oligárquicomilitar. Como es sabido, durante el periodo de Maximiliano Hernández Martínez, hubo dos asambleas constituyentes: una en 1939 y la otra en 1944. Esto pondría fin a los más de cincuenta años en los que estuvo vigente la Constitución de 1886. Uno de los propósitos iniciales de promulgar una nueva Constitución era lograr la reelección directa de Maximiliano Hernández Martínez ${ }^{39}$. Sin embargo, es constatable que, en las sesiones

que laicidad es algo más reciente ya que aparecería en la historia institucional y jurídica de un Estado.

${ }^{34}$ Fortunato Mallimaci "Entre lo que no es y lo que queremos que sea secularización y laicidad en Argentina", Revista sociedad y religión 20, no. 32-33 (2010).

${ }^{35}$ Malimaci "Entre lo que no es".

${ }^{36}$ Enrique Dussel, Historia de la Iglesia en América Latina: coloniaje y liberación (1492-1972) (Barcelona: Nova Terra, 1972). Este autor incluso trata la realidad de separación entre Iglesia y Estado en diversos países de Latinoamérica.

37 Alain Rouquié, El Estado militar en América Latina (Ciudad de México: Siglo XXI, 1984).

${ }^{38}$ Maximiliano Hernández Martínez fue miembro de la masonería salvadoreña y a la vez, perteneció a la teosofía. Perteneció a la logia Morazán no. 7. Al Respecto consúltese, Revista Shittah, Órgano Oficial de la Gran Logia Cuscatlán 52 (enero-marzo 1950). Para más datos sobre Hernández Martínez puede consultarse el texto de Otto Germán Mejía Burgos, Aliados con Martínez. El papel de los intelectuales en la matanza de 1932 (San Salvador: UCA, 2014).

${ }^{39}$ No se puede negar un gran movimiento dentro y fuera de la Asamblea constituyente para lograr la reelección directa de Maximiliano Hernández Martínez. El partido Pro-Patria, continuamente realizaba 
llevadas a cabo por la Asamblea Constituyente de 1938, volvió a surgir el debate sobre la conveniencia o no de la laicidad del Estado. Nuevamente se harían dos bandos, unos a favor de la laicidad y otros es contra de ella.

\section{Asamblea Constituyente de 1938: \\ Un nuevo debate sobre la laicidad del Estado}

El proceso de gestación de este nuevo texto constitucional fue largo y prolongado. En efecto, el anteproyecto fue realizado en 1935 y llevaba como título "Proyecto de Reformas a la Constitución y Leyes Constitutivas". La comisión redactora estuvo conformada por Escobar Serrano, Cayetano Ochoa y Eduardo Álvarez ${ }^{40}$. Tal como ya se ha dicho, el Diario Oficial y otros impresos de la época muestran que previamente se realizó un acto de votación para elegir a los diputados constituyentes ${ }^{41}$.

Esta Asamblea Constituyente fue instalada en noviembre de 1938. Tal como lo muestran los estudios históricos ${ }^{42}$, se puede observar desde la primera sesión una gran cantidad de mensajes enviados a la Asamblea Constituyente manifestando apoyo a la reelección del General Maximiliano Hernández Martínez. Un día después, cuando se estaba celebrando la segunda sesión, llegó un oficio del arzobispado invitando a los diputados constituyentes a asistir a la toma de posesión del nuevo Arzobispo de la Capital (Monseñor Luis Chávez y González) ${ }^{43}$. Los diputados acuerdan enviar una comisión a dicha ceremonia en señal de cortesía. Dicha comisión la integraron el presidente de la Asamblea Constituyente, el señor Francisco Reyes, diputado por el departamento de Santa Ana $^{44}$ y otros diputados.

Desde la tercera sesión de la Asamblea Constituyente, puede observarse ya el debate sobre aspectos que tocaban las relaciones entre la Iglesia y el Estado. En efecto, uno de los temas más discutidos fue si era necesario hacer la mención de Dios en el prólogo de la

mitines a favor de la continuación del presidente en el poder. Al respecto puede verse, "Mitin del centro obrero tecleño Pro-Martínez”, en El Cívico Tecleño, órgano del C.D. de la asociación cívica salvadoreña, 23 de octubre de 1938, 1.

40 Juan Mario Castellanos, El Salvador, 1930-1960, Antecedentes Históricos de la Guerra Civil (San Salvador: Dirección de Publicaciones e Impresos, 2001), 136. El Anteproyecto se titulaba "Proyecto de Reformas a la Constitución y Leyes Constitutivas".

${ }^{41}$ Por ejemplo, en el Diario oficial del 11 de enero de 1939 se afirma que la Asamblea Constituyente fue electa por sufragio universal los días 23, 24 y 25 de octubre de 1938. En total fueron 210, 810 votos de los ciudadanos. Véase, Diario Oficial, "Cuarta, quinta y sexta sesiones de la asamblea nacional constituyente, celebradas los días 23, 24 y 25 de noviembre del año próximo pasado”, 11 de enero de 1939, 61

${ }^{42}$ Castellanos, El Salvador, 1930-1960, 126-133; Rey Prendes, De la dictadura militar a la democracia, 33.

${ }^{43}$ Luis Chávez y González fue el séptimo obispo de San Salvador y el tercer Arzobispo de la Arquidiócesis de la capital salvadoreña. En su gobierno, publicó más de 52 cartas pastorales sobre diferentes temáticas. Para más información se puede consultar: Rosa Carmelita Samos Stibbs, Sobre el Magisterio Mons. Luis Chávez y González, Estudio teológico de sus cartas pastorales (San Salvador, 1992). Esta última obra originalmente fue una tesis para licenciatura en teología de la Universidad Francisco Marroquín de Guatemala.

44 Santa Ana es una ciudad de El Salvador situada a 64 kilómetros de San Salvador. Tradicionalmente se ha considerado como la segunda ciudad más importante de El Salvador. 
nueva Constitución. Esto era bastante significativo ya que en la Constitución de 1886 no se menciona a Dios en el prólogo. Algunos diputados afirmaban que era necesario hacer dicha mención ya que en el Escudo de El Salvador aparece el nombre de Dios y además, la mayoría de la población del país era creyente ${ }^{45}$. Al respecto, el diputado Serrano dijo en su intervención: "La obra humana que nos proponemos realizar, debe basarse ante todo en la fe en Dios, porque es El a quien el Pueblo Salvadoreño reconoce como autor y creador de todo lo que existe" 46 . Por su parte, otro bloque significativo de diputados estaba en contra de nombrar a Dios en la nueva Constitución. Entre estos resalta la participación del diputado Beltrán Galindo, quien, a pesar de ser católico, opinaba que la Constituyente era una obra puramente humana y, por tanto, mencionar a Dios era mezclar las cosas divinas con las humanas. Esta discusión acabó cuando intervino el diputado por el departamento de La Libertad, Gúzman Dreyfus, quien era masón perteneciente a la logia Morazán no. $7^{47}$. Este diputado pidió que se sometiera a votación este punto para no prolongar demasiado la discusión. Finalmente, con treinta y un votos favorables logró aprobarse que en el prólogo se mencionara a Dios.

De entrada, esto era realmente significativo ya que en la Constitución de 1886 no se menciona a Dios y ahora, 53 años después, el nombre de la divinidad volvía aparecer en un texto constitucional. La reacción de los sectores católicos ante esto no se hizo esperar. Ellos se alegraron por la inclusión del nombre de Dios en el texto de la nueva Carta magna a tal punto que el mismo Arzobispo capitalino enviaría un oficio de felicitación a la Asamblea Constituyente por haber aprobado la mención de Dios en el texto constitucional $^{48}$. A la vez, tal como ya se ha mencionado, con esta situación se podría decir que todo apuntaba a que la nueva constitución sería más acorde a los deseos e intereses de la Iglesia católica que incluso podría apuntar en un futuro a revertir el Estado laico.

\section{Discusión sobre mantener la palabra "laica" en la educación nacional.}

En la décimo sexta sesión de la Asamblea Constituyente ${ }^{49}$, se discutió ampliamente sobre la educación en el país. No podía dejar de aparecer allí el tema de la educación laica. En ese debate el diputado Aguilar exigió explicar el sentido de la palabra "laica" ya que, sin duda, es un término que se presta a múltiples interpretaciones. Ante esto, tomo la palabra el diputado Vásquez afirmando que, en la legislación del país, dicha palabra hay que interpretarla en su sentido exacto, es decir, como aquella educación que no tiene una religión determinada. Esto con la finalidad de alejar de la enseñanza los problemas que puedan tener un origen religioso. Por su parte, el primer secretario de la Asamblea

${ }^{45}$ Diario Oficial, "Tercera sesión de la Asamblea Nacional Constituyente celebrada el 22 de noviembre del año próximo pasado", 8 de enero de 1939, 37.

${ }^{46}$ Diario Oficial, "Tercera sesión de la Asamblea Constituyente", 8 de enero de 1939, 39

47“"Resp:. Log:. Simb:. "Morazán No. 7”, Revista Shittah, Órgano oficial de la Logia Cuscatlán 40 (1948): 39.

48 Diario oficial, "Sexta sesión de la Asamblea Constituyente celebrada el 25 de noviembre de 1938", 11 de enero de 1939.

${ }^{49}$ Diario Oficial, "Décimo sexta sesión de la Asamblea nacional Constituyente celebrada el 15 de diciembre. del año próximo anterior", 8 de febrero de 1939. 
Constituyente, diputado Patrocinio Guzmán Trigueros, dirá que la palabra "laica" está bien definida en el léxico, pero algunos la interpretan como persecución contra quienes tienen y sustentan ideas religiosas lo cual, a su juicio es un error.

Ahora bien, algunos diputados se opusieron a la mención de la palabra "laica" en la educación ya que, de acuerdo a su criterio, al hacerlo, la Asamblea estaba imponiendo la exclusión de la religión en la enseñanza pública con lo cual se estaría atentando contra la libertad que estaba garantizada a toda costa en la Constitución. Su discurso fue muy elocuente y continuaría mostrando las ventajas de la educación religiosa y manteniendo su idea de suprimir la palabra "laica" de la educación. Por su parte, otros diputados estaban a favor de incluir la palabra "laica" en la educación nacional. Por ejemplo, el diputado coronel Barrios Quesada y el diputado Díaz, afirmaron que el Estado salvadoreño debía tener control sobre cualquier tipo de enseñanza que se diera en la República y, por tanto, era necesario consignar la palabra "laica" en el inciso del artículo. Al final de esta sesión se decidió mejorar la redacción del inciso. En las próximas sesiones, este artículo quedaría aprobado por la Asamblea Constituyente de la siguiente forma: "La enseñanza es libre; la primaria es, además, obligatoria. La enseñanza que se dé en establecimientos costeados o subvencionados por el Estado o las municipalidades, será laica. La que se imparta en escuelas o colegios particulares estará sujeta a la vigilancia y al control del Estado" "50. Con esto se seguía con la tradición marcada desde 1886 en donde se establecía que la educación impartida por los centros educativos administrados por el gobierno sería laica. A la vez, a pesar de los deseos de los grupos católicos, en la Constitución de 1939 se volvió a confirmar que la educación del país sería laica cuando fuera impartida por el Estado.

Ciertamente existieron varias discusiones en la Asamblea Constituyente sobre otras temáticas que afectaban las relaciones entre la Iglesia y el Estado ${ }^{51}$. Sin embargo, estas dos referencias que se han mostrado, logran evidenciar que el tema de la laicidad del Estado salvadoreño volvió a estar presente en las discusiones de la Asamblea Constituyente de 1938 que finalmente daría paso a la Constitución que fue proclamada en 1939. En definitiva, puede decirse que los sectores católicos se equivocaron al creer que con la aprobación de la mención del nombre de Dios en el preámbulo de la constitución iba a ser un comienzo para revertir el Estado laico. Más bien, de acuerdo a lo visto, la Constitución de 1939 no modificó el Estado laico ya que siguió promoviendo la libertad de cultos, la educación laica y la prohibición de los clérigos de tener cargos de elección popular. De esta manera, el texto constitucional de 1939 fue una confirmación del Estado laico en El Salvador y las variaciones entre los artículos que trataban los asuntos religiosos fueron mínimos. Véase el siguiente cuadro comparativo.

\footnotetext{
50 Constitución de la República de El Salvador, 1939, artículo 34, http://biblio.juridicas.unam.mx/libros/4/1575/17.pdf

${ }^{51}$ Algunos artículos fueron debatidos con bastante intensidad, aunque al final se aprobaron por unanimidad. Por ejemplo, el texto que habla sobre la libertad de cultos (artículo 27 de la Constitución de 1939) fue discutido y al final aprobado.
} 


\section{Cuadro 1}

Constituciones de 1886 y 1939

Artículo 12.

Artículo 27.

Se garantiza el libre ejercicio de Se garantiza el libre ejercicio de todas las religiones, sin más límite que todas las religiones sin más límite el trazado por la moral y el orden público. En el ejercicio de sus que el trazado por la moral y el funciones deberán abstenerse los ministros de los cultos religiosos, de orden público. Ningún acto religioso poner su autoridad espiritual, al servicio de intereses políticos. Ningún servirá para establecer el estado acto religioso posterior a la creación de Registro civil en la República civil de las personas. $\quad$ servirá para establecer el estado civil de las personas.

Artículo 33. Artículo 54.

La enseñanza es libre: la primaria, La enseñanza es libre; la primaria es, además, obligatoria. La enseñanza es, además obligatoria. La que se dé en establecimientos costeados o subvencionados por el Estado enseñanza que se dé en los o las municipalidades, será laica. La que se imparta en escuelas o establecimientos costeados por el colegios particulares estará sujeta a la vigilancia y al control del Estado. Estado, será laica y 013 gratuita, y La enseñanza procurará la formación moral, la educación cívica y el estará sujeta a los reglamentos perfeccionamiento personal y profesional de los salvadoreños.

respectivos.

El Estado y los Municipios están obligados, de manera especial a incrementar la enseñanza primaria, costeando las escuelas necesarias al efecto en las cuales se impartirá gratuitamente.

También deberá el Estado fomentar la enseñanza secundaria y profesional de artes y oficios y toda actividad cultural; pero los establecimientos que costee o subvencione, con tal objeto, serán organizados y controlados directamente por el Poder Ejecutivo.

Sólo el Estado podrá expedir o autorizar títulos académicos para el ejercicio de profesiones liberales en la República de conformidad con la ley.

En ningún establecimiento de enseñanza podrá hacerse distinción alguna para admitir alumnos, a menos que tal distinción se refiera a los fines especiales del establecimiento

Elaboración propia tomando como fuentes las constituciones de 1886 y 1939 de El Salvador.

\section{Reacción católica a los debates constitucionales}

Los sectores católicos estuvieron muy atentos a lo que ocurría dentro de los debates constitucionales sobre todo con los asuntos que estuvieran vinculados a la Iglesia católica. En efecto, pronto reaccionaron ante lo que ocurría en las sesiones de la Asamblea Constituyente. Veamos algunos ejemplos de esto. Por razones de espacio se hará referencia solamente a dos situaciones. La primera de ellas ya se ha señalado líneas atrás al mostrar los mensajes de felicitación enviados por el nuevo arzobispo de San Salvador, monseñor Luis Chávez y González, luego de que la Asamblea Constituyente aprobara mencionar a Dios en el nuevo texto constitucional. Esto iba a ocurrir a finales de 1938.

Otro punto de reacción católica va a ser un memorial que enviarán los obispos católicos del país a los diputados constituyentes en enero de 1939, es decir, a unos días de aprobar el texto constitucional definitivo. Dicho documento se titula "Memorial de los prelados salvadoreños a la Asamblea Nacional Constituyente" ${ }^{52}$. En este texto, los obispos

\footnotetext{
${ }^{52}$ El texto apareció reproducido íntegramente en la edición de Criterio el día 5 de febrero de 1939.
} 
de El Salvador pedirán la derogación de leyes que a criterio de ellos lesionaban grandemente los derechos de la Iglesia católica. En realidad, lo que pedían era la supresión de algunos artículos que ya habían sido aprobados por parte de la Asamblea Nacional Constituyente. Entre dichos artículos estaba el inciso segundo del artículo 27 en donde se prohibía a los ministros del culto realizar política en sus celebraciones, y el artículo 54, el cual que se refería a la educación laica. En este último punto pedirán urgentemente a los diputados quitar la palabra "laica" de la educación ya que ella ha producido mucho daño a las nuevas generaciones del país. Decían los obispos:

Más de media centuria llevamos de imposición de escuela laica. (Decimos imposición porque fue obra del sectarismo masónico en la Asamblea Constituyente del 86 contra la manifiesta voluntad y protestas del Soberano Pueblo Salvadoreño), y los luengos años de desarrollo del fatídico sistema laico, son más que suficientes para conocer sus amargos frutos de corrupción. La escuela laica en El Salvador se ha sostenido no por la fuerza de la razón, sino por la razón de la fuerza por despótica imposición. Por sus frutos los conoceréis. Árbol de frutos podridos es la ESCUELA LAICA [...] ¡Hay que volver a Dios!... SALVEMOS LA PATRIA!! ¡iVOLVAMOS A LA FE DE NUESTROS PADRES!! ¡¡VOLVAMOS A DIOS!! ${ }^{53}$.

No obstante, lo anterior, los diputados no darían marcha atrás a lo que ya habían aprobado e hicieron caso omiso a esta petición de los obispos salvadoreños. Esto también trajo una reacción de los sectores laicistas ya que algunos intelectuales salvadoreños opinaban que no bastaba con decir constitucionalmente que la educación es laica. Había que dar más pasos para que ello se volviera realidad. Así, José F. Figeac ${ }^{54}$ afirmaba en un escrito que a pesar de que la educación es laica, la influencia de la Iglesia católica en la enseñanza no oficial es muy alta y considerable. A su juicio lo que debería de hacerse es tener leyes secundarias que garantizaran la enseñanza laica a nivel nacional. Además, Figeac mostraba su descontento porque la mayor parte de los profesores en colegios católicos del país eran extranjeros lo cual contradecía una ley existente en El Salvador de esta época que manifestaba que en toda institución educativa, el ochenta por ciento de la planta docente debía ser nacional ${ }^{55}$. En ese sentido, el profesor Figeac pedirá una constante

\footnotetext{
${ }^{53}$ Criterio, "Memorial de los prelados salvadoreños a la Asamblea Nacional Constituyente", 5 de febrero de 1939, 1.

${ }^{54}$ José F. Figeac fue un intelectual y profesor salvadoreño. Fue un activo defensor de la educación laica desde finales de la década de los años treinta hasta alrededor de 1960. Fungió como Director de la Biblioteca Nacional "Francisco Gavidia" de San Salvador. Aunque no aparece en los listados de las logias masónicas salvadoreñas, al parecer si tuvo parientes que se habían iniciado en la masonería en el siglo XIX y principios del siglo XX. Así, la obra de Francisco J. Ponte muestra a Carlos Flores Figeac (posible antepasado de José F. Figeac) como miembro de la masonería. Al respecto consúltese, Ponte, Historia de la masonería salvadoreña, 36-40.

${ }^{55}$ En 1931 cuando era presidente Arturo Araujo se había aprobado un decreto que prohibía momentáneamente el ingreso de sacerdotes religiosos extranjeros al país. Para más datos puede consultarse, "Fue aprobada por la Asamblea Nac. una ley injusta y sectaria" en El Tiempo, 1 de junio de 1931, 1. Nótese que esto sucedió antes de que Maximiliano Hernández Martínez fuera presidente.
} 
supervisión de las autoridades a los colegios católicos ${ }^{56}$.

Finalmente, como una reacción más a estos debates constitucionales estaría la visión de la prensa católica salvadoreña. Hacer referencia a los periódicos católicos es vital y necesario ya que ellos eran uno de los principales medios encargados de difundir y propagar el pensamiento de los grupos católicos del momento. En dichos escritos, notas o artículos editoriales se hacía referencia a otros países en donde el catolicismo iba ganando terreno. $\mathrm{O}$ bien se reproducían textos aparecidos en otros periódicos y revistas católicas del extranjero en donde se atacaba la enseñanza laica, el comunismo, el liberalismo, el protestantismo, entre otros temas. Esto se explorará a continuación.

\section{Críticas al liberalismo y al comunismo en la prensa católica salvadoreña}

Como ya se ha dicho en las líneas anteriores, la Constitución de 1939 trajo consigo un nuevo debate sobre la laicidad del Estado salvadoreño. Quizás el debate no fue tan intenso como el que había ocurrido en 1886 pero lo cierto es que nuevamente volvió a salir el tema religioso dentro de las sesiones de la Asamblea Constituyente. En ese contexto y como dato relevante, se puede decir que la prensa católica va a tener un rol muy importante en esta etapa ya que fue el medio que tenían los sectores católicos para difundir sus ideas y mostrar que era mejor un Estado confesional pro-católico que un Estado con enfoque laico. De esta manera, a través de diferentes impresos fueron vertidas críticas hacia el liberalismo, la masonería y el comunismo por considerarlos peligrosos para los intereses católicos y, además, porque a criterio de los redactores de estos textos estos grupos promovían una división entre la Iglesia y el Estado. Por supuesto, también se criticarían otros grupos que con el pasar del tiempo iban ganando varios adeptos como el protestantismo, la teosofía o el espiritismo, pero eso bien daría para otra investigación más amplia en donde se podría ver la crítica de los sectores católicos contra todo tipo de disidencia. A continuación, se hará referencia a tres situaciones. La primera estribaría en ver cómo la prensa católica en su afán de demostrar que era mejor un Estado confesional, se dedicó a evidenciar ejemplos de otros países en donde el catolicismo iba ganando terreno e imponiéndose a visiones laicas.

\section{La constante referencia de la prensa católica a países en donde el catolicismo iba ganando terreno}

Un punto crucial de los sectores católicos para realizar propaganda a su favor fue el hacer continuas referencias al contexto internacional en los documentos escritos. De esta manera, mostrarían lo que ocurría en otros países. Así, en múltiples textos aparecidos en la prensa católica, se enaltecía a las naciones que daban prioridad y privilegios a la Iglesia

\footnotetext{
${ }^{56}$ Jose F. Figeac, “Monopolizan la enseñanza religiosos extranjeros”, Diario Latino, 11 de agosto de 1939, 4.
} 
católica y, a la vez, se tenía una visión negativa y condenatoria de los países que separaban el poder civil del poder eclesiástico.

Por poner un ejemplo de lo anterior, en la edición del 14 de julio de 1940 de Criterio se hace mención del Concordato entre la Iglesia católica y Portugal. Dicho Concordato contenía 31 artículos entre los que destacaba un reconocimiento jurídico a la Iglesia católica ${ }^{57}$. A la vez, en otros textos publicados en este periódico se hacían continuas referencias al régimen de Francisco Franco en España. Al respecto, el día 5 de marzo de 1939, apareció una nota titulada "Derogación de la ley de secularización de cementerios en España" ${ }^{58}$. Ahí se muestra que en España se había derogado una ley que venía desde 1932 y con lo cual, a juicio del redactor, se hacía justicia ya que se le devolvía a la Iglesia y a las parroquias los lugares sagrados de los cementerios ${ }^{59}$. Como es sabido, desde 1931 se había instaurado en España la Segunda República. Durante este tiempo sus gobernantes fomentaban un Estado laico que le quitaba privilegios a la Iglesia católica. En ese tiempo se había dado la ley de secularización de los cementerios y ahora en tiempo de la dictadura de Franco se derogaba y se devolvía al catolicismo ${ }^{60}$ En el caso de España, se estaba dando lo que podríamos llamar una vuelta al Estado confesional luego de pasar por un breve periodo de laicidad durante la Segunda República. Esto ciertamente, llamaba la atención a los grupos católicos de El Salvador ya que hacía pensar y suponer que allí también podía pasar y realizarse algo similar.

Las referencias a América latina no podían faltar. Para muestra de ello, el día 21 de junio de 1939 apareció en Chaparrastique la nota "Crucifijo en las escuelas" realiza un comentario sobre Argentina. El editor de la nota manifiesta que Argentina es un país avanzado en materia educativa porque acababa de mandar a colocar un crucifijo en todas las escuelas lo cual venía a significar un retroceso a un proceso de laicidad del Estado. En efecto, al buscar fuentes sobre lo que ocurría en Argentina en estos años se puede constatar que en lo educativo se intentó desterrar lo laico y promover una educación religiosa. Era la época del gobierno en donde los dirigentes de la educación nacional de ese período de tiempo eran personas afines a la Iglesia católica. Incluso se ha llegado a decir que estas personas tenían la idea de ver al catolicismo como el principio organizador de la sociedad $^{62}$. Como se puede notar, con estas referencias la prensa católica salvadoreña de este período de tiempo tenía como una de sus finalidades crear una opinión pública favorable de las naciones que daban privilegios a la Iglesia católica posiblemente para

\footnotetext{
${ }^{57}$ Criterio, "Nuevo Concordato entre Portugal y la Santa Sede", 14 de julio de 1940, 1.

${ }^{58}$ Criterio, "Derogación de la ley de secularización de cementerios en España", 5 de marzo de 1939, 4.

${ }^{59}$ Como es sabido, desde 1931 hasta 1939 se instauró en España la Segunda República. Hay varios estudios que atestiguan el vínculo de la masonería con la Segunda República Española. Al respecto consúltese, Ferrer Benimeli, Masonería española contemporánea (Madrid: Siglo XXI, 1980), 64.

${ }^{60}$ Las relaciones entre la Iglesia católica y el régimen de Francisco Franco han sido muy estudiadas por los ambientes académicos. Al respecto consúltese: Julián Casanova y Julia Casanova, La Iglesia de Franco (Madrid: Crítica, 2001).

${ }^{61}$ Chaparrastique, "Crucifijo en las escuelas", 21 de junio de 1939, 5.

${ }^{62}$ Susana Bianchi, "Catolicismo y peronismo. Iglesia católica y Estado en Argentina, 1945-1955", Revista Trocadero 8-9 (1997).
} 
mostrar que en El Salvador también se podía revertir el Estado laico haciendo este tipo de iniciativas.

\section{Críticas al comunismo}

En la misma línea, a la hora de criticar al comunismo, las alusiones al contexto internacional no se hicieron esperar. Por ejemplo, en una edición de Criterio apareció el artículo "Alarmante penetración comunista" ${ }^{63}$. El texto probablemente es una reproducción aparecida en la nación mexicana. Ahí el escritor de este texto muestra lo peligroso de la penetración de las ideas comunistas en México desde la revolución, a tal punto que de seguir así, México se convertirá en un comisariato de Moscú y en un pueblo desgraciado y miserable alejado de la religión ${ }^{64}$. Hay también referencias a Costa Rica. En efecto, el 26 de febrero de 1939 apareció la nota titulada "La mano tendida en Costa Rica" ${ }^{65}$. En realidad, este texto era una reproducción aparecida en la revista "Cartas de Roma". Allí el redactor de esta nota muestra el considerable éxito que había tenido el Partido Comunista de Costa Rica en las últimas elecciones. A la vez, se hace alusión a un discurso del líder Manuel Mora que realizó en 1938 y que fue reproducido en las páginas del periódico El Diario de Costa Rica. En esta reproducción aparecida en Criterio, se hará un resumen del discurso y al final se lanzan críticas a los comunistas enfatizando que es un horror que aún en los rincones más distanciados y alejados de Moscú se tienen el mismo tipo de ideas comunistas que tantos males ha causado a los pueblos. Por supuesto, puede deducirse que, al reproducir las notas anteriores, los editores de Criterio tenían en mente crear un miedo entre la feligresía al comunismo y sus ideas. Evidentemente, ese no sería un detalle baladí ya que, en efecto, la cercanía geográfica a México y Costa Rica era un llamado de atención para que estuvieran alerta los grupos católicos ante las ideas comunistas que se difundían en el ambiente.

También hay un considerable número de textos en donde criticarán a lo que ellos llaman "la España roja". Un ejemplo, que ilustra esto es en la edición del 8 de enero de 1939, en donde aparecerá en la primera página de Criterio un texto titulado "Quince millones de dólares en propaganda roja" "66. Ahí se muestra las declaraciones del Dr. A. Hamilton, profesor de Harvard en donde menciona que la embajada de España roja es dirigida por un descendiente de judíos llamado Don Fernando de los Ríos. De acuerdo al profesor, este judío llevaba ya gastados quince millones de dólares en propaganda comunista en la nación del norte. Por otro lado, en ese mismo texto, el profesor de Harvard afirmó que se siente avergonzado de que más de 69 ministros de la Iglesia episcopaliana hayan firmado un documento en favor de la España roja. Finaliza el texto expresando su

\footnotetext{
${ }^{63}$ Criterio, "Alarmante penetración comunista", 19 de marzo de 1939, 3.

${ }^{64}$ Abundará referencias al comunismo de Rusia. Por ejemplo, el periódico Chaparrastique tiene un texto llamado "Contradicciones del materialismo bolchevique", 28 de enero de 1938, 1.

${ }^{65}$ Criterio, "La mano tendida en Costa Rica", 26 de febrero de 1939, 1.

${ }^{66}$ Criterio, "Quince millones de dólares en propaganda roja”, 8 de enero de 1939, 1.
} 
admiración por el catolicismo al ser éste un baluarte de la civilización cristiana ${ }^{67}$.

Al respecto es llamativo, un texto aparecido también un día de septiembre de 1939 que se titula "Los rojos españoles saquearon nuestro consulado general en Barcelona"68. En dicho escrito, el editor de Criterio enfatiza que este es un hecho criminal que no debe quedar ignorado por parte de los salvadoreños. También se aprovecha este hecho para hacer una fuerte crítica a los sectores de izquierda salvadoreños que simpatizaban con las ideas socialistas. Nos dice el texto aparecido en Criterio:

Ya nos imaginamos el cotorro de verduleras que nuestros izquierdistas solapados y democrateros hubieran armado si por necesidades militares las fuerzas del Ejército Nacional de la España auténtica hubieran tenido que hacer cosa parecida aunque nunca igual con el Consulado de Basutolandia, por ejemplo! Y si no, está el caso de la reciente ruptura de relaciones entre el Gobierno de la madre Patria y el frente Popular de una Nación digna de mejor suerte en el sur del continente, que ha dado lugar a democrateros, cocodrilos, lloricones y comunistas solapados de todas las categorías para pretender echar lodo, hiel y vinagre ala España nacional ${ }^{69}$.

Como se puede observar, en este contexto se promovió en los escritos católicos una fuerte crítica hacia el comunismo, situación que ya se venía dando desde hace muchos años en diferentes textos de los obispos salvadoreños. En efecto, Monseñor José Alfonso Belloso y Sánchez (antecesor de monseñor Luis Chávez y González) había escrito ya dos cartas pastorales condenando el comunismo ateo. Una apareció en $1927^{70}$ y la otra, diez años después $^{71}$. Dicha Carta pastoral lo que hacía era enfatizar ciertos puntos de la Encíclica del Papa Pio XI "Divini Redemptoris". Evidentemente se tenía la percepción de que el comunismo podía llevar a la herejía y al error, ya que promovía posturas ateas y contrarias a la fe. De esto dieron cuenta otros periódicos y revistas afines a la Iglesia católica. Así, en el periódico Buen Pastor editado en Atiquizaya ${ }^{72}$, se decía que los comunistas son los culpables de los males que padece El Salvador y la feligresía debía estar atenta ante este tipo de ideas que podían perjudicar gravemente la fe. Decía el editor de Buen Pastor:

¡Qué horror nos causa solo oír esos dos nombres: comunismo y comunistas! Con

\footnotetext{
${ }^{67}$ Noticias sobre este punto continuarían siendo presentadas con gran intensidad. Por ejemplo, el día 29 de enero apareció en primera página el texto "Un Arzobispo Norteamericano desenmascaró a Ríos". En este contexto es interesante que al decir que el embajador Ríos es judío, se está vinculando el comunismo con el judaísmo.

${ }_{68}$ Criterio, "Los rojos españoles saquearon nuestro consulado general en Barcelona", 1 de septiembre de 1939, 1. De acuerdo a la noticia, el Consulado salvadoreño en Barcelona fue invadido y saqueado en esos días. Sin embargo, dicha noticia no la he podido contrastar con otras fuentes.

${ }^{69}$ Criterio, "Los rojos españoles saquean nuestro consulado", 1.

${ }^{70}$ Monseñor José Alfonso Belloso y Sánchez, "Pastoral del administrador Apostólico de San Salvador sobre el presente momento social”, (San Salvador: Tipografía La Unión, 1927).

${ }_{71}$ Monseñor José Alfonso Belloso y Sánchez "Carta Pastoral del Exmo y Rvmo. Señor Arzobispo de San Salvador dando conocer a sus diocesanos la Encíclica "Divini Redemptoris" de nuestro padre Pio XI" (San Salvador: Tipografía la Unión, 1937).

${ }^{72}$ Atiquizaya es una ciudad ubicada en el departamento de Ahuachapán a $88 \mathrm{~km}$ al oeste de San Salvador.
} 
pena y espanto hemos lamentado las tristes consecuencias y estragos causados por los comunistas en esta República. Con horror recordamos los sucesos del 22 de enero y los días siguientes del año 1932. No menos espanto nos causa recibir y leer tristes noticias de los espantosos acontecimientos que han tenido lugar en España en estos días pasados y que no terminan. Con pena recordamos las profanaciones llevadas a cabo en nuestro templo parroquial en manos comunistas, en este mismo año. Si nos horroriza ver cómo Dios se ha valido del comunismo para castigar a España, Rusia y México, etc. ¿Qué nos espera en nuestra república en donde ha sentado sus reales esa infernal doctrina? ${ }^{73}$

En definitiva, estos textos muestran una visión negativa sobre el comunismo y los países gobernados por regímenes así eran vistos por los sectores católicos como tiranías. Conviene decir aquí que también los gobiernos militares salvadoreños veían con malos ojos al comunismo $^{74}$ lo cual vendría a ser una coincidencia entre la postura católica y la gubernamental aunque desde diferentes puntos de vista. Sin embargo, dicho situación y relación sería objeto de otra investigación.

\section{Fuertes críticas a la masonería y al liberalismo}

El periódico Criterio siempre mostró una dura crítica a la masonería en diversos artículos y notas que escribían los redactores de este periódico católico. Por ejemplo, en muchos textos se advertía a los católicos de los riesgos de pertenecer a esta institución o de las sanciones a los que estaban sometidos sus miembros. Así, en un texto titulado "De verdadero interés"75 se hace alusión al artículo 2,335 del Código de derecho canónico en donde se recuerda que los miembros que pertenezcan a la masonería están excomulgados y por tanto no pueden recibir los sacramentos ni recibir digna sepultura.

A veces esta crítica llegaba hasta la ironía y burla hacia los miembros masones. Esa burla se unía a ciertas prácticas que eran prohibidas por la Iglesia católica de ese momento, como, por ejemplo, la cremación de cadáveres. Sobre esto hay un texto titulado "Chiharrones laicos. Dedicado simbólicamente al fotógrafo preguntón. Escenas tragicómicas de la cremación de cadáveres humanos" "76. Ahí se narra la historia ficticia de Don Lemes Cochineta, masón del grado 33, de la logia “Gran Rabo de Lucifer" que decidió no enterrar a su padre, sino que lo cremó. Vino un día a visitarle su amigo Don Burrini y confundió las cenizas con rapé y comenzó a sorber las cenizas con la nariz dándose una gran pelea con Don Lesmes Cochineta al presenciar tal acto.

Paralelo a esto, también hay muchos textos en donde se critica al liberalismo o a las

\footnotetext{
${ }^{73}$ Buen Pastor, "No queremos comunismo ni comunistas", 1 de marzo de 1938, 4.

${ }^{74}$ Alfredo Ramírez, "El discurso anticomunista como factor de la guerra civil en El Salvador 1967-1972", en Poder, actores y conflictividad, ed. Carlos Gregorio López Bernal (San Salvador: DPI, 2011), 317-348.

${ }^{75}$ Criterio, "De verdadero interés", 1 de septiembre de 1940, 2.

${ }^{76}$ Criterio, "Chicharrones laicos". 8 de septiembre de 1940, 4.
} 
posturas laicistas. Por ejemplo, en Chaparrastique apareció el texto "Laicismo femenil"77 en donde se remarcaba de los peligros que corre el sector femenino ante la amenaza de las ideas y posturas laicas. A la vez, sobre el mismo tema, en Criterio apareció un comentario del profesor Manuel Melgar en donde muestra una visión negativa al laicismo. Afirma Manuel Melgar:

¡Qué ciegos y torpes son los laicizadores del pueblo! Tiene ojos y no ve, tiene entendimiento y no entienden que son ellos, precisamente, los principales causantes del mal. Han arrebatado al pueblo su fe de antaño y por ende la base ùnica y segura de toda moralidad, y ahora quieren remediar las casas acudiendo a infantiles recursos[...]. En el orden espiritual y moral el laicismo es poderoso para destruir, pero es impotente para construir. Se edifica sobre arena, con aparente hermosura y consistencia, pero a la largo solo se logra amontonar escombros de inmoralidad y corrupción $^{78}$.

Como dato adicional, un hecho importante a remarcar es que la condena a la masonería continuaría dándose en documentos escritos que aparecerían fuera de la prensa católica. Uno de ellos sería el texto titulado "Carta Pastoral colectiva de los Reverendísimos Prelados de la Provincia Eclesiástica de El Salvador, Sobre las Sectas Condenadas por la Iglesia"79. Este documento vio la luz el día 21 de noviembre de 1940 durante la festividad de la Presentación a la Santísima Virgen. Entre esas sectas condenadas por la Iglesia católica aparecería mencionada la masonería.

Poniendo otro ejemplo, en algunos artículos la crítica a la masonería se unía a la crítica al liberalismo. Así, a solo tres meses de haberse aprobado el texto Constitucional de 1939, que había en general vuelto a confirmar una Constitución con enfoque laico, los redactores de Criterio, reproducían un texto titulado "Catolicismo Político" aparecido en la revista "Cartas de Roma". Ahí se lanzaría una crítica conjunta a los liberales y masones. Decía dicho documento:

La Iglesia depositaria de la verdad divina, no puede renunciar a su deber de enseñar a los hombres no solo sus obligaciones individuales, sino también sus deberes cívicos y sociales. También la vida pública, en lo que concierne a la moral, cae bajo la jurisdicción de la Iglesia. Negar esto, es recaer en el viejo error liberal, impuesto por la masonería en el siglo pasado ${ }^{80}$.

Como puede verse, en la mentalidad católica del siglo XX estaba aún muy presente la tarea y labor que había realizado la masonería en el siglo XIX para promover la laicidad en algunos países. En el caso de El Salvador los dirigentes de la Iglesia católica aún tenían

\footnotetext{
${ }^{77}$ Basilio Plantier, “Laicismo Feminil”, Chaparrastique, 3 de diciembre de 1939, 5.

78 Manuel Melgar, "Laicismo", en Criterio, 15 de abril de 1940, 4.

${ }^{79}$ El texto fue consultado en el Archivo de la Conferencia Episcopal de El Salvador. Apareció también en Criterio en la edición del día 5 de febrero de 1939 en la primera página.

${ }^{80}$ Criterio, "Catolicismo político", 30 de abril de 1939, 3.
} 
muy viva la influencia de la masonería por fomentar una educación laica y la libertad de cultos a nivel constitucional lo cual puede verse en los debates de la asamblea constituyente que dio origen a la Carta magna de 1886.

Para finalizar, se mostrará un último caso en donde se evidencia el vínculo de la crítica al liberalismo con las críticas al comunismo. Un artículo del día 7 de julio de 1940 titulado "Los ismos que se combaten en Europa" $" 11$ manifestaba que:

El liberalismo y el socialismo, cada uno a su manera, son antisociales y enemigos de la libertad. Uno so color de proteger la persona y el otro fingiendo preocuparse por la sociedad y el bien colectivo, ambos en mayor o menor grado, según el punto a donde lleguen en la aplicación de sus teorías, que pueden ser desde el supercapitalismo sin entrañas hasta el trágico y abominable extremo del comunismo bolchevique, conducen a los mismos resultados: falta de paz, desorden, opresión de la muchedumbre, negación de la personalidad humana ${ }^{82}$.

Situaciones como las anteriores abundan en la prensa católica salvadoreña de esta época. De hecho, cuesta hallar un día en donde no se encuentre un artículo, opinión o nota que haga referencia a la masonería, el liberalismo o el comunismo. A la vez se expresaba el temor que cualquiera de estos enemigos pudiera llevar a la ruina al país, así como lo habían hecho con otras naciones. Es interesante tal como se ha mostrado en las últimas referencias que en ocasiones se unía la crítica a la masonería con las críticas al liberalismo o comunismo. Esto recuerda lo que en otro contexto se llamó la conspiración Judeomasónica-comunista ${ }^{83}$. En efecto, tal como lo muestra José Antonio Ferrer Benimeli, durante el tiempo de la dictadura de Franco fue muy difundido dicho contubernio llegando a considerar a los masones, comunistas y judíos como los grandes enemigos de la España católica. También en la historia de Francia durante la ocupación Nazi se habló en algunos medios del complot comunista-masónico. Lo anterior era falso ya que en la historia puede rastrearse que algunos regímenes comunistas también persiguieron a la masonería ${ }^{84}$. Sin embargo, la unión entre estas esferas (comunismo-masonería) era vital para una construcción teórica de los enemigos. En el caso de los grupos católicos, el construir esta unión sobre falsedades era un medio eficaz para formar una opinión desfavorable de estos grupos.

\footnotetext{
${ }^{81}$ Criterio, "Los ismos se combaten en Europa"7 de julio de 1940, 1.

82 "Los ismos se combaten", 1.

${ }^{83}$ Ferrer Belimelli, El contubernio Judeo-Masónico-Comunista (Madrid: Editorial Itsmo, 1982).

${ }^{84}$ Marco Novarino, "Las resoluciones antimasónicas de la Internacional Comunista y sus repercusiones en Francia y España", en La Masonería en la España del siglo XX, coord. Ferrer Benimelli (Toledo: Universidad de Castilla-La Mancha y CEHME, 1996), 489-507.
} 


\section{Conclusión}

Ante todo, lo anteriormente expuesto podemos concluir que el debate constitucional sobre la laicidad del Estado salvadoreño fue nuevamente abierto cuando el General Maximiliano Hernández Martínez decidió en 1938 convocar a una Asamblea Constituyente para modificar la Constitución de 1886. Ante esto, los sectores católicos vieron que esa era la gran oportunidad para revertir los artículos laicizantes que afectaban directamente a la Iglesia Católica desde hace más cincuenta años. Es así como se profundiza una fuerte crítica hacia el liberalismo, el comunismo y la masonería en la prensa católica salvadoreña al considerarlos enemigos de la Iglesia. A la vez, los sectores católicos tenían todavía muy vivo en el recuerdo que cincuenta y tres años atrás la masonería había promovido la laicidad del Estado en la Carta Magna de 1886 y por tanto no vacilarán en lanzar una visión negativa de esta institución en los impresos católicos. En efecto, los impresos católicos eran uno de los principales vehículos que difundían las ideas y creaban opinión pública de los grupos católicos.

Además, es interesante constatar que a pesar de que la Constitución de 1939 volvió a confirmar los artículos laicizantes de la Constitución de 1886, los sectores católicos a través de los medios de comunicación no se desanimaron en sus ideas y a lo largo de 1939 y 1940 continuaron promoviendo y demostrando que los Estados internacionales que promovían y defendían a la Iglesia Católica habían logrado grandes avances, mientras que las naciones que apoyaban un Estado laico iban encaminadas hacia la ruina. Esto probablemente lo escribían con el fin de mostrar que en El Salvador también podían darse a futuro cambios de esas magnitudes y tener un Estado con Constitución y leyes que dieran privilegios a la Iglesia católica.

Lo cierto es que el tema del Estado laico todavía estaba vivo en la esfera pública y la prensa católica da cuenta de ello. Esto conllevó a realizar profundas críticas a todo tipo de disidencia que incluía a liberales, comunistas y masones, acusando a estos últimos de ser los principales responsables de que en el país se tuviera una educación laica y pocos privilegios a la Iglesia católica a nivel constitucional. Lo cierto es que esto nos muestra que el debate sobre el Estado laico iba a continuar durante buena parte del siglo XX y en efecto, cada vez que se diera una reforma constitucional este tema volvería a salir. El discurso católico era similar al del siglo XIX respecto al liberalismo y la masonería. Sin embargo, hoy entraba en juego un nuevo enemigo: el comunismo. 
Anexo

Cuadro 2

Logias masónicas establecidas en El Salvador a inicios de la década de 1940

\begin{tabular}{|c|c|}
\hline Logia & Departamento \\
\hline Rafael Reyes no. 1 & San Salvador \\
\hline Excélsior 17 no. 3 & San Salvador \\
\hline Reforma no. 4 & Sonsonate \\
\hline Morazán no. 7 & San Salvador \\
\hline Fénix no. 9 & San Salvador \\
\hline Lux no. 8 & San Salvador. \\
\hline
\end{tabular}

Fuente: Revista Shittah, Órgano Oficial de la logia Cuscatlan 15 (1940).

\section{Fuentes primarias}

Belloso y Sánchez, José. "Pastoral del administrador Apostólico de San Salvador sobre el presente momento social”. San Salvador: Tipografía La Unión, 1927.

Belloso y Sánchez, José. "Carta Pastoral del Exmo y Rvmo. Señor Arzobispo de San Salvador dando conocer a sus diocesanos la Encíclica "Divini Redemptoris" de nuestro padre Pio XI”. San Salvador: Tipografía la Unión, 1937.

Buen Pastor 1938.

Carta Pastoral Colectiva de los Reverendísimos Prelados de la Provincia Eclesiástica de El Salvador, Sobre las Sectas condenadas por la Iglesia. San Salvador, 21 de noviembre de 1940.

Constitución de El Salvador, San Salvador, 1886.

Constitución de El Salvador, San Salvador, 1939.

Constitución Política de la Monarquía Española de 1812. Madrid, Edición conjunta de la Agencia Estatal Boletín Oficial del Estado, la Biblioteca Nacional de España, el Centro de Estudios políticos y Constitucionales y el consorcio para la Conmemoración del II Centenario de la Constitución de 1812.

Diario Oficial 1938, 1939.

Diario Latino 1939.

El Cívico Tecleño, órgano del C.D. de la asociación cívica salvadoreña 1938.

El Tiempo, Diario católico de información y de intereses generales 1931.

Chaparrastique 1938, 1939.

Criterio 1939, 1940.

Memorial de los Prelados Salvadoreños a la Asamblea Nacional Constituyente. San Salvador, 10 de enero de 1939.

Patria 1938.

Prisma semanario independiente 1939.

Revista Shittah, Órgano oficial de la Logia Cuscatlán 1940, 1948, 1950. 


\section{Bibliografía}

Ayala, Luis Ernesto. La Iglesia y la Independencia Política de Centroamérica (1808-1832). San Salvador: Editorial Don Bosco, 2011.

Baubérot, Jean. “Sécularisation, laïcite, laïcisation”. Epam 90 (2013): 31-38.

Bianchi, Susana. "Catolicismo y peronismo. Iglesia católica y Estado en Argentina, 19451955". Revista Trocadero 8-9 (1997).

Cardenal Rodolfo. El Poder Eclesiástico en El Salvado. San Salvador: CONCULTURA, 2001.

Casanova Juliá y Julia Casanova. La Iglesia de Franco. Madrid: Editorial Crítica, 2001.

Castellanos, Juan Mario. El Salvador, 1930-1960, Antecedentes Históricos de la Guerra Civil. San Salvador: Dirección de Publicaciones e Impresos, 2001.

Castro Rivera, Edwin y Calderón Marenco Margine. Derecho Constitucional Nicaragüense. Managua: Colección Facultad de Ciencias Jurídicas UCA, 2007.

Clara Resplandis, Joseph. "Masonería y la Segunda República: El caso de Girona". En Masonería, política y sociedad. Editado por José Antonio Ferrer Benimeli. Sevilla: Centro de Estudios Históricos de la Masonería Española, 1989.

Chanta Martínez, René. "Antimasonería y antiliberalismo en el pensamiento de Oscar Arnulfo Romero". REMHLAC 3, no. 1 (mayo-noviembre 2011): 121-141. https://revistas.ucr.ac.cr/index.php/rehmlac/article/view/6589

Delgado, Jesús. Historia de la Iglesia en El Salvador. San Salvador: Dirección de Publicaciones e Impresos, 2013.

Dussel, Enrique. Historia de la Iglesia en América Latina: coloniaje y liberación (14921972). Barcelona: Nova Terra, 1972.

Fernández Sarasola, Ignacio. La Constitución de Bayona (1808). Madrid: IUSTEL, 2007.

Fernández Sarasola, Ignacio. "La primera Constitución española. El estatuto de Bayona”. Revista de derecho 26 (2006).

Ferrer Benimeli, José Antonio. El contubernio Judeo-Masónico-Comunista. Madrid: Editorial Itsmo, 1982.

Ferrer Benimeli, José Antonio. Masonería española contemporánea. Madrid: Siglo XXI, 1980.

Ferrer Benimeli, José Antonio. "Utopía y realidad del liberalismo masónico. De las cortes de Cádiz a la independencia de México”. En 300 años: masonerías y masones 1717-2017. Tomo I. Migraciones. Editado por Ricardo Martínez Esquivel, Yván Pozuelo Andrés, Rogelio Aragón. México, Palabra de Clío, 2017.

González Torres, Julián. "Del ciudadano Católico al ciudadano laico". Tesis de doctorado en filosofía iberoamericana, Universidad Centroamericana "José Simeón Cañas", 2012.

Gallardo, Ricardo. Las Constituciones de El Salvador. Madrid: Ediciones Cultura Hispánica, 1961. 
Gallardo Ricardo. Cuatro constituciones federales de Centroamérica y las constituciones políticas de El Salvador. San Salvador: Tipografía La Unión, 1945.

Laboa, Juan María. Historia de la Iglesia. IV Época contemporánea. Madrid: Biblioteca de Autores Cristianos, 2002.

Lindo, Héctor. La economía de El Salvador en el siglo XIX. San Salvador: CONCULTURA, 2002.

López Vallecillos, Ítalo. El periodismo en El Salvador. San Salvador: UCA Editores, 1987.

Martina, Giacomo. La Iglesia de Lutero a nuestros días. Madrid: Ediciones Cristiandad, 1974.

Mallimaci, Fortunato. "Entre lo que no es y lo que queremos que sea secularización y laicidad en Argentina". Revista Sociedad y religión 32-33 (2000).

Mejía Burgos, Otto. Aliados con Martínez. El papel de los intelectuales en la matanza de 1932. San Salvador: UCA, 2014.

Mercader Riba, Juan. José Bonaparte, Rey de España (1808-1813). Madrid: Consejo superior de investigaciones científicas, 1983.

Novarino, Marco. "Las resoluciones antimasónicas de la Internacional Comunista y sus repercusiones en Francia y España”. En La Masonería en la España del siglo XX. Coordinado por José Antonio Ferrer Benimeli. Toledo: Universidad de Castilla-La Mancha y CEHME, 1996.

Olano García Hernán. La Constitución de Bayona. Precursora del constitucionalismo hispanoamericano. Bogotá: Academia colombiana de jurisprudencia, 2014.

Ponte, Francisco. Historia de la masonería salvadoreña. Sonsonate: Imprenta Excelsior, 1962.

Ramírez, Alfredo. "El discurso anticomunista como factor de la guerra civil en El Salvador 1967-1972”. En Poder, actores y conflictividad. El Salvador 1786-1972. Editado por Carlos Gregorio López Bernal. San Salvador: DPI, 2011.

Rey Prendes, Julio. De la dictadura militar a la democracia. Memorias de un politico salvadoreño 1931-1994. San Salvador: INVERPRINT, 2009).

Rouquié Alain. El Estado militar en América Latina. Ciudad de México: Siglo XXI, 1984.

Samos Stibbs, Rosa Carmelita. Sobre el Magisterio Mons. Luis Chávez y González, Estudio teológico de sus cartas pastorales. San Salvador: Imprenta Criterio, 1992.

Vásquez Monzón, Olga. "El debate sobre la educación femenina en el contexto de la laicización del Estado salvadoreño (1871-1889)". Tesis de doctorado en filosofía iberoamericana, Universidad Centroamericana "José Simeón Cañas", 2012.

Vásquez Oliveira, Mario. La República Federal de Centroamérica, territorio, nación y diplomacia, 1823-1836. San Salvador: Editorial Universidad José Matías Delgado, 2013.

Valdés Valle, Roberto. "Masones, liberales y ultramontanos salvadoreños: Debate político y Constitucional en algunas publicaciones impresas, durante la etapa final del proceso de secularización del Estado salvadoreño (1885-1886)". Tesis de doctorado 
en filosofía iberoamericana, Universidad Centroamericana "José Simeón Cañas", 2010.

Valdés Valle, Roberto. “Origen, miembros y primeras acciones de la masonería en El Salvador". REHMLAC 1, no. 1 (mayo-noviembre 2009): 155-171. https://revistas.ucr.ac.cr/index.php/rehmlac/article/view/6861/6548

Valdés Valle, Roberto. "El Porvenir vs El Católico. Masonismo y ultramontanismo periodístico en confrontación”. Revista Realidad de Ciencias Sociales y humanidades 126 (2001): 547-581.

Vega, Juan Ramón. Las 54 Cartas Pastorales de Monseñor Luis Chávez y González. San Salvador: Ediciones del Arzobispado de San Salvador, 1997. 